\author{
見島牛における遺伝性疾患、毛色、経済形質に関わる \\ 遺伝子座の対立遺伝子の分布 \\ 米田一裕 ${ }^{1 *}$ ・渡辺望 ${ }^{2 *} \cdot$ 国枝哲夫 ${ }^{2}$ \\ 1 有限会社 米田遺伝子型研究所 $=569-1017$ 大阪府高梘市成合北の町 774-2 \\ 2 岡山大学大学院自然科学研究科、 $\bar{T} 700-8530$ 岡山市北区津島中 1-1-1 \\ *これらの 2 著者は本研究に同等に貢献した
}

\title{
Allelic distribution of loci associated with hereditary diseases, a coat color, and economical traits in Mishima cattle
}

\author{
Kazuhiro Yoneda $^{1 *}$, Nozomi Watanabe ${ }^{2 *}$, and Tetsuo Kunieda ${ }^{2}$ \\ ${ }^{1}$ Yoneda Genotyping laboratory Ltd. ,Nariaikitanomachi, Takatsuki, Osaka 569-1017, Japan. \\ ${ }^{2}$ Graduate School of Natural Science and Technology, Okayama University, Tsushima-naka, Okayama, 700-8530, Japan \\ * These two authors equally contributed to this work.
}

\begin{abstract}
Mishima cattle is a rare breed originated from Japanese native cattle and has been registered as national natural treasure of Japan. Various polymorphisms of genes associated with economical traits such as growth rate, beef marbling and fatty acid composition, and mutant alleles of genes responsible for hereditary diseases have been identified in Japanese Black cattle, but no data regarding these polymorphism and mutant alleles in Mishima cattle has been reported. Therefore, we investigated whether these polymorphisms and mutant alleles are existing in Mishima cattle in this study. We genotyped F11, LYST and $C L 16$ genes responsible for factor XI deficiency, Chediak-Higashi syndrome, and renal tubular dysplasia, respectively, MC1R gene involved in coat color, $E D G 1, S C D$ and $S R E B P 1$ genes associated with beef marbling and fatty acid composition, and POU1F1 and GHR genes associated with growth rate in DNA samples of ten Japanese Black cattle and eleven Mishima cattle. Consequently, no mutant alleles of F11, LYST and CL16 loci, $E^{+}$allele of MC1R locus, and $G$ allele of EDG1 locus was observed in the samples of the Mishma cattle examined. On the other hand, two alleles were observed in $S C D, S R E B P 1$, POU1F1 and GHR loci in the samples of the Mishima cattle as in the case of the Japanese Black cattle, although there frequencies were different between these two breeds. These findings will be informative for investigating the genetic characteristics of the Mishma cattle.
\end{abstract}

Key words: Genoetype, polymorphism, Mishima cattle, mutant allele

\section{要 約}

見島牛は、現在日本に存在する数少ない在来牛の一つであり国の天然記念物に指定されている。これまでに、黒 毛和種などにおいて増体や脂肪交雑、脂肪酸組成などの生産形質に関わる遺伝子の多型、遺伝性疾患に関する突然 変異遺伝子の存在が明らかにされているが、見島牛におけるこれらの変異あるいは多型に関する報告はこれまでに ない。そこで本研究では、これらの形質に関連する遺伝子の変異あるいは多型が見島牛にも存在するか検討した。 黒毛和種 10 個体抒よび見島牛 11 個体の DNA サンプルを用い、遺伝性疾患の第 XI 因子欠乏症、チェディアック ・ ヒガシ症候群、尿細管形成不全症の原因遺伝子である F11、LYST およびCL16 遺伝子、毛色に関与することが知 
られている $M C 1 R$ 遺伝子、脂肪交雑や脂肪酸組成に関与することが報告されている $E D G 1 、 S C D$ および $S R E B P 1$ 遺伝子、増体等に関与する可能性のあるPOU1F1 とGHR 遺伝子について PCR 法あるいは PCR-RFLP 法によりそ の遺伝子型を調べた。その結果、今回調べた見島牛中には、LYST、CL16 およびF11 遺伝子座に扔ける変異対立 遺伝子、 $M C 1 R$ 遺伝子における $E^{+}$対立遺伝子、 $E D G 1$ 遺伝子座における $G$ 対立遺伝子は検出されなかった。一方、 $S C D 、 S R E B P 1 、 P O U 1 F 1$ および GHR 遺伝子では、その頻度に違いはあるものの、黒毛和種と同様に二つの対立 遺伝子が見島牛中にも存在していることが明らかになった。これらの結果は、見島牛の遺伝的特性を考える上で重 要な知見であると考えられた。

\section{緒言}

我が国固有の肉用牛である和牛は、明治以降に肉用 牛としての諸形質を改良する目的で、日本の在来牛に いくつかの外国品種を交雑することで確立されてい る。その中でも黒毛和種は、現在、和牛の飼育頭数の 9 割以上を占めているが、一方で外国品種との交雑の ない純粋の在来牛はほとんど姿を消したといわれてい る。しかし、山口県萩市の見島で飼育されている見島 牛は、日本の在来牛としての特徽を残す数少ないもの として知られ、国の天然記念物にも指定されている (Nagamine ら 2008)。その特徵は、体型は小型で被毛 色は黒色を呈し、筋繊維は細く、優れた脂肪交雑を持 つことが知られている。特にその脂肪交雑の遺伝的能 力は、例えばホルスタインとの交雑個体においても優 れた脂肪交雑を示すことが知られており、和牛におけ るこれら形質の改良のための遺伝子資源としても注目 されている。

現在、脂肪交雑や増体など和牛の経済形質に関わる 遺伝子 (Taniguchi ら 2004; Zhao ら 2004; Hoashi ら 2007 ; Yamada ら 2009a)、和牛生産上の不良形質とな る遺伝性疾患の原因遺伝子 (Kunieda ら 1999 ; Ohba ら 2000 ; Hirano ら 2000 ; Yamakuchi ら 2000 ; Kunieda 2005 ; Kunieda ら 2005)、毛色に関する遺伝 子 (Klungland ら 1995; Sasazaki ら 2005) が同定され、 これらの形質に関する遺伝子型の判別法も確立されて いる。さらに、黒毛和種におけるこれらの生産形質や 遺伝性疾患に関する対立遺伝子の集団内での頻度も明 らかにされ (Sasazaki ら 2005 ; Ohkubo ら 2006； Watanabe ら 2010)、黑毛和種の育種改良にも利用さ れている。一方、見島牛は、優れた脂肪交雑などの特 徵を有する和牛成立の基となった在来牛であるにも関 わらず、その遺伝的特徵はほとんど明らかにされてい ない。そこで、本研究では見島牛の DNA サンプルを 用いて、和牛で見られる主な遺伝性疾患の原因遺伝子 であるF11、CL16 抢よびLYST 遺伝子、毛色に関与 することが知られている $M C 1 R$ 遺伝子、脂肪交雑や脂
肪酸組成に関与することが報告されている $E D G 1 、$ $S C D$ および $S R E B P 1$ 遺伝子、増体等に関与する可能 性のある POU1F1 と GHR 遺伝子について、PCR 法あ るいは PCR-RFLP 法により遺伝子型を調べることで、 見島牛の遺伝的特徵の一端を明らかとすることを目的 とした。

\section{材料および方法}

山口県萩市見島より財団法人動物繁殖研究所白老牧 場に導入され、飼育されていた 11 頭の見島牛種雄牛 の凍結保存精液よりゲノム DNA を抽出した。黒毛和 種については複数の県からランダムに得られた 10 個 体の血液よりゲノム DNA を抽出した。凍結精液から の DNA の抽出は、融解した凍結精液を ProteinaseK $(0.25 \mathrm{mg} / \mathrm{ml}) 、 2-$ Mercaptoethanol $(5 \%)$ を含む溶液 中にて $55{ }^{\circ} \mathrm{C} て ゙ 12$ 時間反応させた後、RNase A $(0.25$ $\mathrm{mg} / \mathrm{ml})$ を加え $37{ }^{\circ} \mathrm{C} て ゙ ~ 45$ 分反応させ、その後フェノー ル/クロロホルム抽出、エタノール沈殿させることに より行った。血液からの DNA 抽出は、ProteinaseK $(0.25$ $\mathrm{mg} / \mathrm{ml})$ を含む溶液中にて $55{ }^{\circ} \mathrm{C} て ゙ ~ 12$ 時間反応させた 後、RNaseA $(0.25 \mathrm{mg} / \mathrm{ml})$ を加え $37{ }^{\circ} \mathrm{C} て ゙ ~ 45$ 分反応 させ、その後フェノール/クロロホルム抽出、エ夕ノー ル沈殿させることにより行った。DNA 濃度は $260 \mathrm{~nm}$ の波長の吸光度から算出した。

PCR は、20 ng の DNA、0.5 $\mu \mathrm{M}$ のプライマー、 0.2 $\mathrm{mM}$ の dNTP、 $0.25 \mathrm{u}$ の Taq ポリメラーゼを含む 10 $\mu \mathrm{l}$ の PCR 反応液中にて、伸長温度 $72{ }^{\circ} \mathrm{C}$ で 30-120 秒、 変成温度 $94{ }^{\circ} \mathrm{C}$ で 30-60 秒、Table 1 に記載の各プライ マーに対応したアニーリング温度で 30-60 秒を 1 サイ

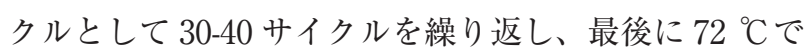
300 秒の伸長反応を行った。その後、F11、SREBP1 お よび $G H R$ 遺伝子については、増幅された $\mathrm{PCR}$ 産物を 直接 $3 \%$ アガロースゲルにて $100 \mathrm{~V} て ゙ 30$ 分間電気泳動 を行ったのち、臭化エチジウム染色により可視化し、 増幅断片の長さの違いにより遺伝子型を判別した。 CL16 遺伝子については、正常対立遺伝子小よび変異 
対立遺伝子に特異的なプライマーを用いて PCR 増幅 を行い、アガロースゲル電気泳動により、それぞれの プライマーにより断片が増幅されるか否かにより遺伝 子型を判別した。LYST、MC1R、EDG1、SCD および POU1F1 遺伝子については、PCR 増幅産物を特定の制 限酵素にて消化の後、同様にアガロースゲル電気泳動 を行い、制限酵素断片の長さの違いにより遺伝子型を 判別した。制限䤉素による消化は、各酵素に至適な塩 濃度の反応液にて $37{ }^{\circ} \mathrm{C} て ゙ 30$ 分間行った。各遺伝子に ついてのプライマーの配列、増幅断片の長さ、アニー リング温度、PCR-RFLP 法の場合に用いた制限酵素を Table 1 に示した。なお、これらのプライマーのうち、 F11、LYST、CL16 拈よびGHR 遺伝子については文 献に記載の配列のプライマー (Kunieda ら 1999; Hirano ら 2000 ; Kunieda ら 2005 ; Ohkubo ら 2006) を用いたが、 $M C 1 R 、 E D G 1 、 S C D 、 S R E B P 1$ および
POU1F1 遺伝子については、文献に記載の方法 (Klungland ら 1995; Taniguchi ら 2004 ; Zhao ら 2004 Hoashi ら 2007 ; Yamada ら 2009a) を参考に、 本研究において新たな配列のプライマーを設計した。 また $S C D$ 遺伝子については文献に記載の制限酵素と 異なる制限䤄素（FauI）を用いた。

\section{結果および考察}

黒毛和種に発生が報告されている第 XI 因子久乏症 は、F11 遺伝子の第 9 エクソンへの $15 \mathrm{bp}$ の挿入が原 因変異 (-) であることが明らかにされている（Kunieda ら 2005)。この変異について PCR 法により遺伝子型を 判別した結果、黒毛和種においては+/+が 4 個体、 +/-が 4 個体、-/-が 2 個体であるのに対し、見島牛に おいては 11 個体全てが+/+であった（Fig.1）。同様 にチェデイアック・ヒガシ症候群の原因変異 (-) である

Table 1. Primer sequences, fragment lengths, annealing temperatures, and restriction enzymes for genotyping.

\begin{tabular}{|c|c|c|c|c|}
\hline Gene & Primer sequence $\left(5^{\prime}-3^{\prime}\right)$ & Length* & Temp. & Enzyme \\
\hline \multirow[t]{2}{*}{ F11 } & TCACATCTCAATATGTGCTTCTGC & $95,110 \mathrm{bp}$ & 60 & \\
\hline & TCTACGATGTCCAGTTCTTCTCC & & & \\
\hline \multirow[t]{2}{*}{ LYST } & GAAAATTACAGCAGAAGTCCTTGG & $108 \mathrm{bp}$ & 60 & FokI \\
\hline & TGACAAACATAAGTATTAGTAGGAGG & $66,42 b p$ & & \\
\hline CL16 & TATGCTGTTGATGTTTATGTAG & $375 b p$ & 57 & \\
\hline (Normal) & CCCCCCCCCGCCTTTTTC & & & \\
\hline CL16 & ATTGTATTTTTAGGAGTGACTC & $722 \mathrm{bp}$ & 57 & \\
\hline (Mutant) & СССССССССАСТСТАТАС & & & \\
\hline \multirow[t]{2}{*}{$M C 1 R$} & TGGTGAGTCTCGTGGAGAACG & $224 \mathrm{bp}$ & 65 & MspAI \\
\hline & TCGATGACATTGTCCAACTGCTGC & $159,65 \mathrm{bp}$ & & \\
\hline \multirow[t]{2}{*}{$E D G 1$} & AGCTGCACAGATCCGGCGG & $258 \mathrm{bp}$ & 58 & MscI \\
\hline & TGCGCGCTCGGCATCTTGC & $200,158 \mathrm{bp}$ & & \\
\hline \multirow[t]{2}{*}{$S C D$} & TGCTTCATCCTGCCCACACTC & $280 \mathrm{bp}$ & 65 & FauI \\
\hline & GTTTTTCTGGCACGTAACCTAATACC & $200,80 \mathrm{bp}$ & & \\
\hline \multirow[t]{2}{*}{ SREBP1 } & CCACAACGCCATCGAGAAACGCTAC & $694,778 b p$ & 60 & \\
\hline & TTCTGGTTGCTGTGCTGAAGGAAGCGG & & & \\
\hline \multirow[t]{2}{*}{ POU1F1 } & АААССАТСАТСТСССТТСТТ & $454 \mathrm{bp}$ & 56 & Hinf I \\
\hline & AATGTACAATGTCCTTCTGAG & $247,207 \mathrm{bp}$ & & \\
\hline \multirow[t]{2}{*}{ GHR } & TGCGTGCACAGCAGCTCAACC & $0.7,2.0 \mathrm{~kb}$ & 60 & \\
\hline & GGCAAACAGTGCGGGGTTGGA & & & \\
\hline
\end{tabular}

*Italicized letters indicate lengths of digested fragments. 
LYST 遺伝子の塩基置換（Kunieda ら 1999 ; Yamakuchi ら 2000）を制限酵素FokI を用いた PCR-RFLP 法にて、尿細管形成不全症の原因変異 (-) であるCL16 遺伝子の $37 \mathrm{~kb}$ の欠失 (Hirano ら 2000 ; Ohba ら 2000）については正常対立遺伝子、変異対立遺伝子に 特異的なプライマーを用いた PCR 法にて調べた結果、 今回調べたすべての黒毛和種および見島牛中には変異 対立遺伝子は検出されなかった（Fig. 1)。

ほ乳類の毛色に関与するメラノコルチンの受容体で ある $M C 1 R$ 遺伝子の第 1 エクソンにおける塩基置換に より決定される $E^{D} と E^{+}$の遺伝子型について、制限醳 素Msp A1 を用いた PCR-RFLP 法にて調べた。 $E^{D}$ は 黒色、 $E^{+}$は黒褐色の毛色を呈する対立遺伝子である (Klungland ら 1995)。その結果、黒毛和種では 2 個体 が $E^{D} / E^{D} 、 8$ 個体が $E^{D} / E^{+}$であるのに対し、見島 牛では 11 個体全てが $E^{D} / E^{D}$ となり、 $E^{+}$対立遺伝子 は検出されなかった（Fig. 1)。

脂肪交雑形成に関与する $E D G 1$ 遺伝子では、5’ 非
翻訳領域における $\mathrm{A}$ から $\mathrm{G} へ の$ 塩基置換が、脂肪交 雑に正の効果を持つことが報告されている（Yamada ら 2009a ; Sukegawa ら 2010)。この塩基置換を制限 酵素 MSCI を用いた PCR-RFLP 法にて調べた結果、黒 毛和種では 1 個体が $A / A 、 8$ 個体が $A / G 、 1$ 個体が $G / G$ であったのに対し、見島牛では 11 個体全てが $A /$ $A$ であり $G$ 対立遺伝子は検出されなかった（Fig. 1)。

$\mathrm{SCD}$ 遺伝子は、飽和脂肪酸を不飽和脂肪酸に変換し、 肉の食味に関与することが知られているが、この遺伝 子の第 5 エクソンに拈けるにバリンからアラニンへの アミノ酸置換を引き起こす $\mathrm{T}$ から $\mathrm{C} へ の$ 塩基置換が、 不飽和脂肪酸の含量に正の効果を持つことが報告され ている（Taniguchi ら 2004）。この塩基置換を制限䣲 素FauIを用いたPCR-RFLP 法にて調べた結果、黒毛 和種では 6 個体が $V / V 、 4$ 個体が $V / A$ であったのに 対し、見島牛では 2 個体が $V / A 、 9$ 個体が $A / A$ であっ た (Fig. 1)。同様に脂肪酸の組成に関与することが報 告されている $S R E B P 1$ 遺伝子では、第 5 イントロンに
Mishima
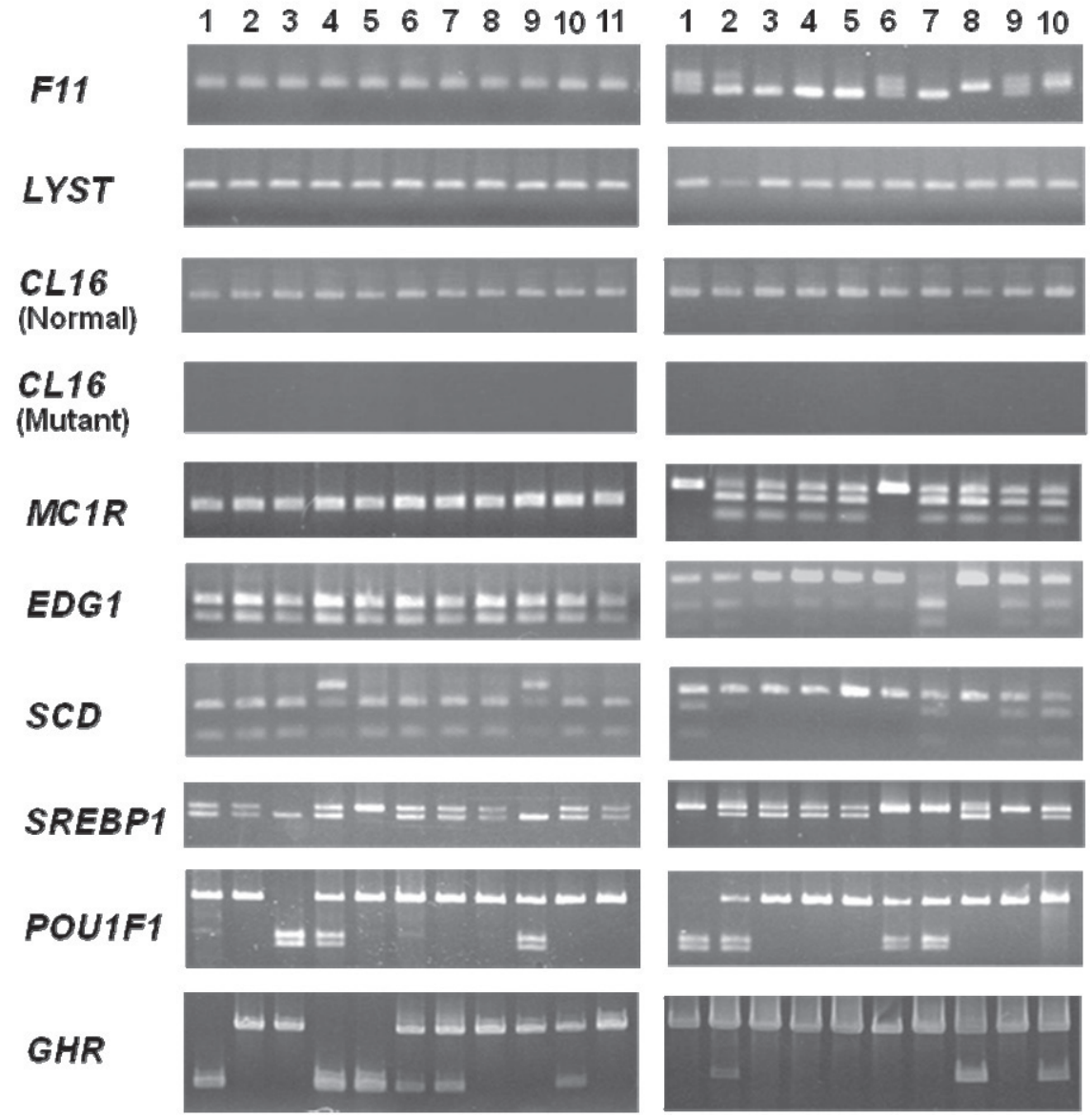

Fig. 1. PCR and PCR-RFLP analyses of 8 genes in Mishima and Japanese Black cattle. PCR products were electrophoresed through $3 \%$ agarose gels and visualized by ethidium bromide staining. 
おける $84 \mathrm{bp}$ の欠失を持つ $S$ 型が、持たない $L$ 型に比 べて不飽和脂肪酸の含有量が多いと報告されている (Hoashi ら 2007)。この変異について PCR 法により判 別した結果、黒毛和種では 4 個体が $L / L 、 6$ 個体が $L /$ $S$ であったのに対し、見島牛では 1 個体が $L / L 、 8$ 個 体がL/S、2 個体がS/Sであった（Fig. 1)。

$P O U 1 F 1$ 遺伝子は、成長ホルモン遺伝子の発現を制 御する転写調節因子 Pit-1 の遺伝子であり、第 6 エク ソンに㧍ける $\mathrm{G}(A$ 型 $)$ から $\mathrm{A}(B$ 型 $)$ への塩基置換 が生産形質に影響することが報告されている（Zhao ら 2004）。この塩基置換を制限酵素 HinfI を用いた PCRRFLP 法にて調べた結果、黒毛和種では 6 個体が $A / A$ 、 3 個体が $A / B 、 1$ 個体が $B / B$ であったのに対して、見 島牛では 8 個体が $A / A 、 2$ 個体が $A / B 、 1$ 個体が $B /$ $B$ であった（Fig. 1)。同様に $G H R$ 遺伝子は成長ホル モン受容体の遺伝子であり、上流領域における約 1.2 $\mathrm{kb}$ のレトロトランスポゾン LINE-1 配列の有無による 多型が生産形質に関与する可能性が報告されている (Ohkubo ら 2006)。この LINE-1 配列の有無を、挿入 部位を挟むプライマーを用いた PCR 法により調べた 結果、黒毛和種では 7 個体が $L / L 、 3$ 個体が L/S であ るのに対し、見島牛では 5 個体が $\mathrm{L} / \mathrm{L} 、 3$ 個体が $L / S$ 、 3 個体が $S / S$ であった（Fig. 1 )。

以上の結果をまとめると、今回調べた見島牛では遺 伝性疾患に関するF11、CL16 拈よび LYST 遺伝子、 毛色に関与する $M C 1 R$ 遺伝子、脂肪交雑に関与する $E D G 1$ 遺伝子では、変異対立遺伝子あるいは多型は検 出されなかった（Table 2)。調べた見島牛の個体数が 11 個体と少ないため断定することはできないが、見島 牛の集団自体が 100 頭前後と小さいため、これらの遺 伝子における変異対立遺伝子あるいは多型は見島牛の 集団には存在しない可能性が高いものと考えられた。 一方、脂肪酸組成に関与する $S C D$ と $S R E B P 1$ 遺伝子、 増体に関与する $P O U 1 F 1$ と $G H R$ 遺伝子では、黒毛和 種と同様に見島牛でもこれら遺伝子の多型が存在する ことが明らかとなった（Table 2)。このように、いく つかの遺伝子で黒毛和種と見島牛の間で明らかな違い が認められたことについては、見島牛の集団が極めて 小さく他の集団とは隔離されていることから、ボトル ネック効果や遺伝子浮動などによりもともとの在来牛 に存在していた遺伝的多様性が見島牛では消失した、 見島牛に見られない対立遺伝子は、もともと在来牛に は存在せず黒毛和種成立後の過程で交雑された外国品 種に由来する、経済形質に着目した黒毛和種の選抜育 種の過程で、もともと在来牛で低い遺伝子頻度であっ
た特定の対立遺伝子の頻度が増加した、などの可能性 が考えられた。

今回調べた黒毛和種で報告されている遺伝性疾患の 原因遺伝子のうち、CL16 と L YST 遺伝子については、 疾患の発生頻度から黒毛和種の集団内での変異対立遺 伝子の頻度は低い值と考えられている。今回、黒毛和 種の 10 個体でこれら疾患の変異対立遺伝子が検出さ れなかったことは、これらの低い対立遺伝子頻度を反 映した結果と考えられた。一方、F11 遺伝子は黒毛和 種の集団中では $30 \%$ 前後の高い遺伝子頻度であり（未

Table 2. Genotypes of 8 loci in Mishima and Japanese Black cattle.

\begin{tabular}{|c|c|c|c|}
\hline Gene & Genotype & Mishima & $\begin{array}{c}\text { Japanese } \\
\text { Black }\end{array}$ \\
\hline \multirow[t]{3}{*}{$F 11$} & $+/+$ & 11 & 4 \\
\hline & $+/-$ & 0 & 4 \\
\hline & $-/-$ & 0 & 2 \\
\hline \multirow[t]{3}{*}{ LYST } & $+/+$ & 11 & 10 \\
\hline & $+/-$ & 0 & 0 \\
\hline & $-/-$ & 0 & 0 \\
\hline \multirow[t]{3}{*}{ CL16 } & $+/+$ & 11 & 10 \\
\hline & $+/-$ & 0 & 0 \\
\hline & $-/-$ & 0 & 0 \\
\hline \multirow[t]{3}{*}{$M C 1 R$} & $E^{D} / E^{D}$ & 11 & 2 \\
\hline & $E^{D} / E^{+}$ & 0 & 8 \\
\hline & $E^{+} / E^{+}$ & 0 & 0 \\
\hline \multirow[t]{3}{*}{ EDG1 } & $A / A$ & 11 & 1 \\
\hline & $A / G$ & 0 & 8 \\
\hline & $G / G$ & 0 & 1 \\
\hline \multirow[t]{3}{*}{$S C D$} & VIV & 0 & 6 \\
\hline & $V I A$ & 2 & 4 \\
\hline & $A / A$ & 9 & 0 \\
\hline \multirow[t]{3}{*}{ SREBP1 } & $L / L$ & 1 & 4 \\
\hline & $L / S$ & 8 & 6 \\
\hline & $S / S$ & 2 & 0 \\
\hline \multirow[t]{3}{*}{ POU1F1 } & $A / A$ & 8 & 6 \\
\hline & $A / B$ & 2 & 3 \\
\hline & $B / B$ & 1 & 1 \\
\hline \multirow[t]{3}{*}{ GHR } & $L / L$ & 5 & 7 \\
\hline & $L / S$ & 3 & 3 \\
\hline & $S / S$ & 3 & 0 \\
\hline
\end{tabular}


発表データ)、今回の黒毛和種での結果もそれを裏付 けている。また、見島牛ではこれらの変異対立遺伝子 はいずれも検出されず、見島牛の集団中にこれら疾患 の原因となる变異遺伝子は存在しないと考えられた。

見島牛の毛色は、黒毛和種に比べてより黒いことが 知られている。これまでにホルスタイン種では ED の 対立遺伝子にほぼ固定されているのに対し (Maudet と Taberlet 2002)、黒毛和種では $E^{D}$ と $E^{+}$の対立遺伝 子頻度が抢よそ1:1であり (Sasazaki ら 2005)、これ らのことが黒毛和種の比較的褐色がかった黒色の毛色 に反映しているものと考えられている。今回、見島牛 の集団に $E^{+}$対立遺伝子が検出されなかったことは、 見島牛の毛色が黒毛和種に比べて黒いことと矛盾しな いものと考えられた。

見島牛は黒毛和種にも劣らない非常に優れた脂肪交 雑を呈することから、黒毛和種の脂肪交雑に関する遺 伝子は主に在来牛に由来していることが考えられてい る。しかし、本研究では $E D G 1$ 遺伝子に打ける脂肪交 雑に正の効果を持つことが報告されている $\mathrm{G}$ 対立遺伝 子は見島牛には検出されなかった。この結果から、見 島牛における脂肪交雑には EDG1 遺伝子は関与してい ない可能性が示唆された。脂肪交雑に関与する遺伝子 は EDG1 遺伝子以外にもいくつか報告されていること から (Yamada ら 2009b ; Baredse ら 2010)、今後こ れらの遺伝子についても調べることで、見島牛におけ る脂肪交雑に関与する遺伝子を明らかにしていきた い。

\section{文献}

Barendse W, Bunch RJ, Harrison BE. 2010. The effect of variation at the retinoic acid receptor-related orphan receptor $\mathrm{C}$ gene on intramuscular fat percent and marbling score in Australian cattle. Journal of Animal Science, 88 : 47-51.

Hirano T, Kobayashi N, Itoh T, Takasugi A, Nakamaru T, Hirotsune S, Sugimoto Y. 2000. Null mutation of PCLN-1/Claudin-16 results in bovine chronic interstitial nephritis. Genome Research, $10: 659-663$.

Hoashi S, Ashida N, Ohsaki H, Utsugi T, Sasazaki S, Taniguchi M, Oyama K, Mukai F, Mannen H. 2007. Genotype of bovine sterol regulatory element binding protein-1 (SREBP-1) is associated with fatty acid composition in Japanese Black cattle. Mammalian Genome, $18:$ 880-886.
Klungland H, Vage DI, Gomez-Raya L, Adalsteinsson S, Lien S. 1995. The role of melanocytestimulating hormone (MSH) receptor in bovine coat color determination. Mammalian Genome, 6 : 636-639.

Kunieda M, Tsuji T, Abbasi AR, Khalaj M, Ikeda M, Miyadera K, Ogawa H, Kunieda T. 2005. An insertion mutation of the bovine F11 gene is responsible for factor XI deficiency in Japanese Black cattle. Mammalian Genome, 16 : 383-389.

Kunieda T. 2005. Identification of genes responsible for hereditary diseases in Japanese beef cattle. Animal Science Journal, 76 : 525-533.

Kunieda T, Nakagiri M, Takami M, Ide H, Ogawa H. 1999. Cloning of bovine LYST gene and identification of a missense mutation associated with Chediak-Higashi syndrome of cattle. Mammalian Genome, 10 : 1146-1149.

Maudet C, Taberlet PJ. 2002. Holstein's milk detection in cheeses inferred from melanocortin receptor 1 (MC1R) gene polymorphism. Dairy Science, 85 : 707-715.

Nagamine Y, Nirasawa K, Takahashi H, Sasaki O, Ishii K, Minezawa M, Oda S, Visscher PM, Furukawa T. 2008. Estimation of the time of divergence between Japanese Mishima Island cattle and other cattle populations using microsatellite DNA markers. Journal of Heredity, 99 : 202-207.

Ohba Y, Kitagawa H, Kitoh K, Sasaki Y, Takami M, Shinkai Y, Kunieda T. 2000. A deletion of the paracellin-1 gene is responsible for renal tubular dysplasia in cattle. Genomics, $68: 229-236$.

Ohkubo T, Yano H, Takahashi S, Takahashi K, Kimura N, Tanaka M. 2006. Bos indicus type of growth hormone receptor gene is retained in Japanese Black Cattle. Journal of Animal Breeding and Genetics, 123 : 410-413.

Sasazaki S, Usui M, Mannen H, Hiura C, Tsuji S. 2005. Allele frequencies of the extension locus encording the melanocortin-1 receptor in Japanese and Korean cattle. Animal Science Journal, 76: 129-132.

Sukegawa S, Miyake T, Takahagi Y, Murakami H, Morimatsu F, Yamada T, Sasaki Y. 2010. 
Replicated association of the single nucleotide polymorphism in EDG1 with marbling in three general populations of Japanese Black beef cattle. BMC Research Notes, $3: 66$.

Taniguchi M, Utsugi T, Oyama K, Mannen H, Kobayashi M, Tanabe Y, Ogino A, Tsuji S. 2004. Genotype of stearoyl-CoA desaturase is associated with fatty acid composition in Japanese Black cattle. Mammalian Genome, 14 : 142-148.

Watanabe N, Yamada T, Yoshioka S, Itoh M, Satoh Y, Furuta M, Komatsu S, Sumio Y, Fujita T, Sasaki Y. 2010. The $\mathrm{T}$ allele at the $\mathrm{g} \cdot 1471620 \mathrm{G}>\mathrm{T}$ in the EDG1 gene associated with high marbling in Japanese Black cattle is at a low frequency in breeds not selected for marbling. Animal Science Journal, 81 : 142-144.

Yamada T, Itoh M, Nishimura S, Taniguchi Y, Miyake T, Sasaki S, Yoshioka S, Fujita T, Shiga K, Morita M, Sasaki Y. 2009a. Association of single nucleotide polymorphisms in the endothelial differentiation sphingolipid G-proteincoupled receptor 1 gene with marbling in Japanese Black beef cattle. Animal Genetics, 40 : 209-216.

Yamada T, Sasaki S, Sukegawa S, Miyake T, Fujita T, Kose H, Morita M, Takahagi Y, Murakami H, Morimatsu F, Sasaki Y. 2009b. Association of a single nucleotide polymorphism in ribosomal protein L27a gene with marbling in Japanese Black beef cattle. Animal Science Journal, 80 : 631-635.

Yamakuchi H, Agaba M, Hirano T, Hara K, Todoroki J, Mizoshita K, Kubota C, Tabara N, Sugimoto Y. 2000. Chediak-Higashi syndrome mutation and genetic testing in Japanese black cattle (Wagyu). Animal Genetics, 31 : 13-19.

Zhao Q, Davis M, Hines HC. 2004. Associations of polymorphisms in the Pit-1 gene with growth and carcass traits in Angus beef cattle. Journal of Animal Science, 82 : 2229-2233. 